\title{
Diversity and Potential Use of Weeds in Farm Production Systems within the Context of Food Security
}

\author{
Natalia Escobar E, Harol Y. Moreno S, Camilo I. Jarmillo B and Néstor J. Romero J.
}

\begin{abstract}
Weeds are known to grow around different types of crops, where they tend to compete with other plants and cause problems in agricultural production; therefore, a study on floristic composition and diversity of 12 farms was conducted. 4 of these farms had a conventional production purpose (Group 1), 4 more were transitioning to organic (Group 2), and the remaining 4 were oriented towards organic production (Group 3). Farms were located in the province of Sumapaz (Colombia) and distributed across three Life Zones, such as: Premontane Rainforest (PMRF), Low Montane Rainforest (LMRF) and Montane Rainforest (MRF). For specimen collection purposes, a restricted random sampling method was performed. Growers were surveyed to obtain more information on the use of the species identified. Diversity was calculated by using Margalef's index, Simpson's index and Shannon-Wiener's index, along with PAST 2.17, a statistical program. A total of 96 species were listed and distributed among 38 families. The most abundant species were Pennisetum clandestinum in (MRF), (LMRF) and Cynodon plectostachius in (PMRF). The greatest diversity of weeds was obtained in Groups 2 and 3. Different uses of weeds were identified mainly in the fields of animal nutrition and soil improvement through green fertilizers.
\end{abstract}

Keywords - Agroecology, environment, small producers.

\section{INTRODUCTION}

At present, weeds have gained a share in farming systems since the presence of different species within crops has a strong impact on the composition and interaction of crops entomofauna, where beneficial insects are more likely to find alternative prey, shelter, breeding sites and dormancy shelters; besides, weeds provide benefits such as insecticides, fungicides, human and animal food, medicinal benefits and soil conservation and protection[1].

On the other hand, within agro-ecosystems, weeds are plant species that by being associated with crops, create competition and reduce yield. However, in sustainable agriculture weeds are a key element and their use is aimed at improving or solving problems of erosion, cover and soil fertility conservation [2]. In contrast, and as stressed by many authors, these species are very useful in production systems.

Natalia Escobar Escobar, PhD. Universidad de Cundinamarca, Colombia. Harol Yulian Moreno Sabogal, Zoo. Universidad de Cundinamarca, Colombia

Camilo Ignacio Jaramillo Barrios, Ing. Agro. AGROSAVIA., Colombia Néstor Jaime Romero Jola , PhD. Universidad del Tolima
Some of those uses include medicinal benefits, repelling properties due to their allelopathic characteristics, nitrogenfixing features, ornamental and food applications, among other uses [3]. In this vein, the study of weeds and other plant species associated with production systems is essential to understanding their functionality, although considered undesirable, their importance is becoming increasingly evident and they also represent a local resource with great potential, when used in processes within agro-ecosystems.

\section{METHODOLOGY}

\section{A. Location of the study area}

The Sumapaz region includes all temperature zones (pisos térmicos). Due to its variety of climates, in the highest area of the Eastern Zone there is the Montane Rainforest (MRF) at nearly 3,000 m.a.s.l., rainfall between 1,000 and 2,000 $\mathrm{mm} /$ year, and an average temperature between $6^{\circ} \mathrm{C}$ and $12^{\circ} \mathrm{C}$. In the Central Zone, there is the Low Montane Rainforest (LMRF) between 1,800 and 2,000 m.a.s.l., rainfall over 2,000 $\mathrm{mm} /$ year, average temperature is between $12^{\circ} \mathrm{C}$ and $18^{\circ} \mathrm{C}$ and in the Lower Zone, there is the Premontane Rainforest (PMRF) whose rainfall is $1,000 \mathrm{~mm} /$ year and a temperature over $24^{\circ} \mathrm{C}[4]$.

\section{B. Sample design}

Based on the results of a study carried out by Universidad de Cundinamarca on the characterization and typology of organic production systems in the Sumapaz region, 71 growers were surveyed, and the following four dimensions were assessed: economic, social, environmental and technological. A series of variables were compared within each dimension, and an analysis of main components was conducted; results showed three groups: conventional producers interested in organic production (Group 1), conventional producers transitioning to organic (Group 2), and organic producers (Group 3) [5].

Once the three groups were obtained, a stratified random sampling, which determined that four farms should be selected for each group to produce a representative sample was performed. Therefore, 12 farms randomly distributed, 4 per Life Zone, were studied in this project.

The sampling area was based on what was proposed by 
[6] who state that random sampling should be performed with the broadest possible distribution within each production system. Similarly, reports by[7]. [8] explaining that sampling should be done according to the collector's interests, were also considered. Random sampling is recommended so complete sampling can be ensured. Therefore, for the purposes of this study the "restricted random sampling" model proposed by [9] was used (Figure 1).

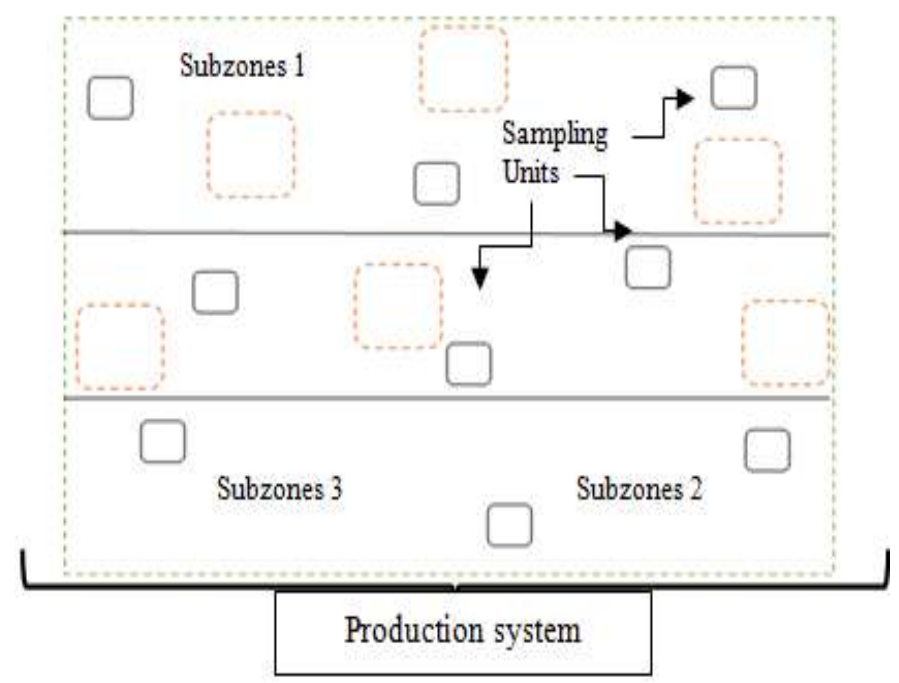

Fig 1. Restricted random sampling model

\section{Calculating diversity}

Diversity for each Life Zone was calculated by using Margalef's index. On the other hand, relative abundance indices such as Simpson's index of dominance and ShannonWiener equity index were used to determine population structure.

These indexes were calculated and compared by using PAST 2.17, a free software for the analysis of scientific data, which performs functions for data manipulation, plotting, univariate and multivariate statistics, ecological analysis, time series and spatial analysis, morphometry and stratigraphy [10].

\section{RESUlTS AND DiSCUSSION}

\section{A. Floristic richness by Life Zones}

Figure 2 shows the floristic richness of the three Life Zones of the study area at the time of highest rainfall with 96 species distributed among 38 families. Findings include: for MRF, 27 species belonging to 17 families, for LMRF, 46 species belonging to 29 families, and for PMRF, 45 species belonging to 18 families.

At the time of lowest rainfall, a total of 81 species were recorded across the three Life Zones, distributed among 35 families. It is worth noting that 63 species coincided in both periods. In addition, (MRF) has the lowest number of species during both highest rainfall and lowest rainfall. Their richness decreases in greater proportion compared to the other two zones (LMRF) and (PMRF); since they show greater richness of flora, they tend to maintain the number of species during lowest rainfall, probably due to association between species, allowing their conservation and protection. The greater the richness of the species in an area, the lower the impact of changes produced by weather phenomena on the flora, landscape and ecosystem composition in general, allowing species conservation in time and space; this is confirmed by [11] who states that ecosystems will be able to maintain themselves in time and space only when their levels of diversity are high, otherwise these ecosystems will begin to lose their capacity to provide their important environmental benefits.

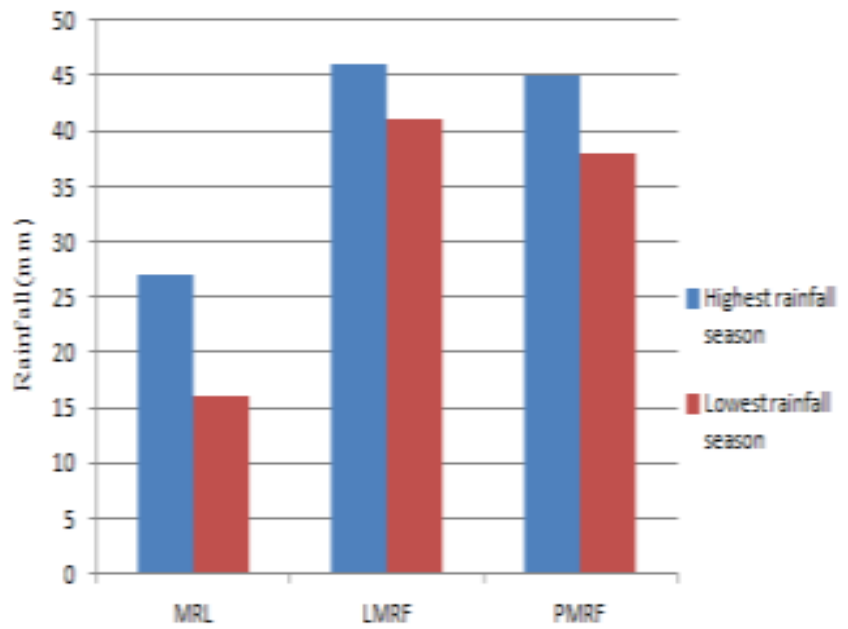

Fig 2. Number of species (richness) by Life Zones during two seasons: highest rainfall $(1000-1750 \mathrm{~mm})$ and lowest rainfall $(0-500$ $\mathrm{mm}$ ).

The most abundant species is Pennisetum clandestinum (Kikuyo grass). In this MRF, main livestock activity is milk production, which is characterized by having emerged after tree felling and burning of the high Andean forests, leaving behind extensive cleared areas used for growing pastures such as Kikuyo and Ray grass [12].

Families found in the LMRF with more than two genera: Poaceae (Antoxhantum, Axonopus, Cynodon, Holcus, Paspalum and Pennisetum), Melastomastaceae (Henriettea, Miconia, Tibouchina, Orthomene) and Fabaceae (Desmodium, Medicago, Erythrina, Trifolium). Pennisetum clandestinum is the most abundant species, as in (MRF). This explains the large altitudinal distribution of this Poacea. In a study carried out in Ecuador by [13] it was found that the distribution and abundance of Pennisetum clandestinum has changed by increasing its altitudinal range, previously between 1,000 and 3,200 m.a.s.1, and now it goes from 1,600 to 3,900 m.a.s.1., which means that this species is a possible indicator of the increase in environmental temperature as a consequence of climate change; this is corroborated by [14]. who states that the rise in altitudinal distribution (altitudinal migration) for some grasses in Colombia could provide some insight into global warming.

Families with more than two genera in PMRF: Asteraceae (Ambrosia, Baccharis, Bindes, Galinsoga, Libonia, Piptocoma, Pluchea, Tithonia, Tridax, Melampodium), Poaceae 
(Axonopus, Chloris, Cynodon, Hyparrhenia, Paspalum, Sporobolus), Fabaceae (Desmodium, Leucaena, Pueraria, Vigna), Euphorbiaceae (Alchornea, Croton, Euphorbia) and Malvaceae (Anoda, Guazuma, Sida). The most abundant species was Cynodon plectostachius. It is commonly found in open pastures, while in forest-to-pasture transition areas it is usually seen in association with other grasses. This grass is one of the many introduced in the American tropics; its distribution nationwide is very broad and it is found in the Departments of Antioquia, Cauca, Choco, Cundinamarca, Huila, Meta, Quindio, Risaralda, Tolima and Valle del Cauca[10].

\section{B. Potential uses of weeds}

Data shown in Table 1 was collected through growers' surveys. It shows services and benefits provided by these plant species. Besides, information highlights "Functional diversity", meaning "The number of identified species with a potential use in agricultural production, in addition to the number of uses that a single species can provide", which accounts for $36,95 \%$ of the species, finding that some have 4 or more uses, being shade and living barriers the most prominent ones.

\section{TABLE I}

POTENTIAL USES OF SPECIES IDENTIFIED ACROSS THE THREE LIFE ZONES

\begin{tabular}{|l|l|l|l|l|l|l|l|l|l|}
\hline \multicolumn{7}{|c|}{ Life Zones } \\
\hline Scientific Name & $\mathrm{A}$ & $\mathrm{B}$ & $\mathrm{C}$ & $\mathrm{D}$ & $\mathrm{E}$ & $\mathrm{F}$ & $\mathrm{G}$ & $\mathrm{H}$ & $\mathrm{I}$ \\
\hline $\begin{array}{l}\text { Alnus } \\
\text { acuminata }\end{array}$ & $\mathrm{X}$ & & & $\mathrm{X}$ & $\mathrm{X}$ & $\mathrm{X}$ & $\mathrm{X}$ & & \\
\hline $\begin{array}{l}\text { Desmodium } \\
\text { triflorum }\end{array}$ & & & $\mathrm{X}$ & & & & & & \\
\hline $\begin{array}{l}\text { Desmodium } \\
\text { uncinatum }\end{array}$ & & & $\mathrm{X}$ & & & & & & \\
\hline $\begin{array}{l}\text { Drymaria } \\
\text { cordata }\end{array}$ & & & $\mathrm{X}$ & & & & & & $\mathrm{X}$ \\
\hline $\begin{array}{l}\text { Erythrina edulis } \\
\text { Hesperomeles } \\
\text { sp. }\end{array}$ & $\mathrm{X}$ & $\mathrm{X}$ & $\mathrm{X}$ & & $\mathrm{X}$ & & & & \\
\hline $\begin{array}{l}\text { Lippa sp. } \\
\text { Medicago } \\
\text { hispida }\end{array}$ & & & $\mathrm{X}$ & $\mathrm{X}$ & & & & & \\
\hline $\begin{array}{l}\text { Miconia } \\
\text { dodecandra }\end{array}$ & & & & & $\mathrm{X}$ & & & & \\
\hline $\begin{array}{l}\text { Oxalis } \\
\text { corniculatus }\end{array}$ & $\mathrm{X}$ & & $\mathrm{X}$ & $\mathrm{X}$ & & & & & $\mathrm{X}$ \\
\hline Rumex patientia & & & $\mathrm{X}$ & & & & & & \\
\hline $\begin{array}{l}\text { Sambucus } \\
\text { peruviana }\end{array}$ & & $\mathrm{X}$ & $\mathrm{X}$ & & $\mathrm{X}$ & & & & \\
\hline $\begin{array}{l}\text { Sida alba } \\
\text { Tibouchina } \\
\text { lepidota }\end{array}$ & & $\mathrm{X}$ & $\mathrm{X}$ & & & $\mathrm{X}$ & & & $\mathrm{X}$ \\
\hline $\begin{array}{l}\text { Tithonia } \\
\text { diversifolia }\end{array}$ & $\mathrm{X}$ & $\mathrm{X}$ & & $\mathrm{X}$ & $\mathrm{X}$ & $\mathrm{X}$ & $\mathrm{X}$ & \\
\hline $\begin{array}{l}\text { Trichanthera } \\
\text { gigantea }\end{array}$ & $\mathrm{X}$ & $\mathrm{X}$ & $\mathrm{X}$ & $\mathrm{X}$ & $\mathrm{X}$ & $\mathrm{X}$ & $\mathrm{X}$ & & $\mathrm{X}$ \\
\hline A. Soil and Fertily & $\mathrm{Imp}$ & & & & & & \\
\hline
\end{tabular}

A. Soil and Fertility Improvers; B. Living Barriers; C. Animal Food;

D. Green Fertilizer; E. Shade; F. Structures; G. Wood; H. Beekeeping; I. Medicinal Benefits

Although growers highlight the importance of some weeds, benefits provided by most of these plants within production units are still unknown. [15] say that cattle ranchers in the
Department of Tolima have called these plant species "Weeds", a term some authors describe as "Those plants whose virtues have not yet been discovered" or "Undesirable plants of low nutritional value found in pastures, which may also be hosts to pests and diseases, both for pastures and animals" [16]. This fact has led to their destruction and eradication in pastures and crops throughout history through the indiscriminate use of herbicides, which in turn poses a threat on desirable species in pastures and crops [17].

Often times, recorded potential uses may be underestimated, partly due to the lack of knowledge around weeds chemical and biological properties; therefore, it is important to carry out a study based on this approach, since diversity of species as a natural resource is still limited. Authors such as [16]. have conducted research on the potential uses of shrubs and trees, stating that they have different uses that can result in a diversified diet for animals and ensure long-term sustainability and ecological balance.

\section{Diversity by Group}

Table 2 shows diversity indexes for the three Groups during two rainfall seasons.

TABLE II

DIVERSITY RATES (SHANNON, SIMPSON Y MARGALEF)

\begin{tabular}{|l|c|c|c|c|c|c|}
\hline \multirow{2}{*}{ RATES } & \multicolumn{2}{|c|}{ GROUP 1 } & \multicolumn{2}{c|}{ GROUP 2 } & \multicolumn{2}{c|}{ GROUP 3 } \\
\cline { 2 - 7 } & $\begin{array}{l}\text { Highest } \\
\text { Rainfall }\end{array}$ & $\begin{array}{l}\text { Lowest } \\
\text { Rainfall }\end{array}$ & $\begin{array}{l}\text { Highest } \\
\text { Rainfall }\end{array}$ & $\begin{array}{l}\text { Lowest } \\
\text { Rainfall }\end{array}$ & $\begin{array}{l}\text { Highest } \\
\text { Rainfall }\end{array}$ & $\begin{array}{l}\text { Lowest } \\
\text { Rainfall }\end{array}$ \\
\hline Taxa $\boldsymbol{S}$ & 41 & 31 & 43 & 33 & 41 & 44 \\
\hline Individuals & 112 & 155 & 135 & 116 & 96 & 114 \\
\hline Shannon H & 3.489 & 3.136 & 3.61 & 3.358 & 3.532 & 3.571 \\
\hline Simpson & 0.963 & 0.9431 & 0.9693 & 0.9612 & 0.9648 & 0.9657 \\
\hline Margalef & 8.477 & 5.948 & 8.562 & 6.732 & 8.764 & 9.079 \\
\hline
\end{tabular}

Group 3 has the greatest richness; that is why, in the case of diversity indexes such as Margalef's, it shows significantly higher values when compared to Group 1 and 2 (p(eq) $<0.001)$. In contrast, when comparing the two seasons in Group 1, there is an important change in the loss of diversity (p(eq) <0.001). The opposite is true for Group 3, which tends to be more stable, as it is for Group 2. This strong difference may be due to the diversity that is present in each of the systems. It can be observed that Simpson's index in Groups 2 and 3 does not vary much, while it does in Group 1. This difference may be the result of some species tending to be more dominant than others, since the conventional model causes alterations when removing undesirable species (trees, shrubs or weeds) by using agrochemicals, deforestation techniques and expansion of pastures for grass growing, which not only alters floristic composition, but also biotic regulation mechanisms, and the normal cycle of agro-ecosystems, mainly nutrient cycling [18]. Meanwhile, when the system is more diversified, natural processes and biological interactions are favored, optimizing synergies resulting in a more selfsufficient system that is able to provide protection against climate change and phenomena and subsidize key processes such as organic matter accumulation and soil fertility [19] by itself. 
Finally, once all structural characteristics of the vegetation found in the 12 farms have been explained, it can be said that changes in the variables measured for the vascular plant species can be associated with the environmental heterogeneity induced by topography or the production model used by said farms. On the other hand, vegetation patterns that are typically observed throughout Life Zones are the result of complex interactions between different factors such as elevation, degree of exposure to solar radiation, topographic position, rainfall, degree of anthropogenic intervention, production orientation, among others [11]. This explains why it is necessary to take into account not only the altitudinal or topographic variables, but also, climate variables and the type of agro ecological system that is being implemented in the farms, in order to have a clearer idea and thus be able to analyze from different perspectives, which are the variables that may possibly affect productivity and systems sustainability in general.

\section{CONCLUSION}

The most abundant species were Pennisetum clandestinum (Kikuyo grass) in (MRF) and (LMRF) and Cynodon plectostachius (Star grass) in (PMRF). According to the Life Zone where Group 3 growers were located, the greatest diversity of weeds was found there, which confirms that organic production has a positive impact on plant diversity.

\section{ACKNOWLEDGMENT}

We would like to thank Universidad de Cundinamarca Research Center for letting us use the facilities and for all the financial support provided to conduct the initial studies that gave rise to this paper.

\section{REFERENCES}

[1] Blanco-Valdes, Y. (2016). El rol de las arvenses como componente en la biodiversidad de los agroecosistemas. Cultivos Tropicales, 37(4), 34-56. Consultado el 20/02/2017.

[2] Blanco, Y. \& A. Leyva. (2010). Abundancia y diversidad de especies arvenses en el cultivo de maíz (Zea Mays L.) precedido de un barbecho transitorio después de la papa (Solanum tuberosum L.). Cultivos Tropicales 31(2): 12-16.

[3] Ávila, V. D., Vargas, J. H. D., \& Castañeda, R. (2015). Desempeño animal de ovinos de pelo colombianos, suplementados con especies arbóreas del bosque seco tropical. Revista Colombiana de Ciencia Animal, 7(1).

[4] Guhl. E, (2007). Aspectos geográficos y humanos de la Región del Sumapáz en la cordillera oriental de Colombia.

[5] Cruz Castiblanco, G. N., \& Jaramillo Barrios, C. I. (2016). Caracterización y tipificación de sistemas de producción orgánica en la región del Sumapaz.

[6] Toral, O. C., Navarro, M. \& Reino, J. (2015) Prospection and collection of species of interest for livestock production in two Cuban provinces. Pastos y Forrajes, 38. (3):157-163

[7] Hoyos, V., Martinez, M. J., \& Plazas, G. (2016). Malezas asociadas a los cultivos de cítricos, guayaba, maracuyá y piña en el departamento del Meta, Colombia. Revista de Ciencias Horticolas, 9(2), 247-258. https://doi.org/10.17584/rcch.2015v9i2.4181

[8] Ramírez, U., J.R. Sanginés, J.G. Escobedo, F. Cen, J.A. Rivera, \& P.E. Lara. (2010). Effect of diet inclusion of Tithonia diversifolia on feed intake, digestibility and nitrogen balance in tropical sheep. Agroforest. Syst. 80:295-302. https://doi.org/10.1007/s10457-010-9320-0

[9] Tendonkeng, F., Pamo, E. T., Boukila, B., Fonteh, F. A., Kana, J. R., \& Nanda, A. S. (2007). Nutritive value of some grasses and leguminous tree leaves of the Central region of Africa. Animal Feed Science and Technology, 135(3), 273-282.

[10] Giraldo-Cañas D. (2013). Las gramíneas en Colombia: Riqueza, distribución, endemismo, invasión, migración, usos y taxonomías populares. Universidad de Colombia, Facultad de Ciencias, Instituto de ciencias Naturales.

[11] Mazzola, M. B., Kin, A. G., Morici, E. F., Babinec, F. J., \& Tamborini, G. (2008). Efect of the altitudinal gradient on the vegetation of Lihue Calel sierras (La Pampa, Argentina). Boletín de la Sociedad Argentina de Botánica, 43(1-2), 103-109.

[12] Stupino, S. A., Ferreira, A. C., Frangi, J., \& Sarandón, S. J. (2007). Agrobiodiversidad vegetal en sistemas hortícolas orgánicos y convencionales (La Plata, Argentina). Revista Brasileira de Agroecologia, 2(1).

[13] Kindon S, Pain R, Kesby M. (eds). 2007. Participatory Action Research Approaches and Methods. Routledge Series in Human Geography. Oxon: Routledge https://doi.org/10.4324/9780203933671

[14] Milestad R, Bartel-Kratochvil R, Leitner H, Axmann P. 2010. Being close: The quality of social relationship in a local organic cereal and bread network in Lower Austria. Journal of Rural Studies 26(3): 228240.

https://doi.org/10.1016/j.jrurstud.2010.01.004

[15] Kindon S, Pain R, Kesby M. (eds). (2007). Participatory Action Research Approaches and Methods. Routledge Series in Human Geography. Oxon: Routledge https://doi.org/10.4324/9780203933671

[16] Landis, D. A.; Wratten, S. D. \& Gurr, G. M. (2000) "Habitat Management to conserve Natural Enemies of Arthropod Pests in Agriculture". Annual Review of entomology, 45(1); 175-201. https://doi.org/10.1146/annurev.ento.45.1.175

[17] Mercado, S. (2000). Índices de integridad biótica de aproximación a su desarrollo. Diversidad biológica de ríos y arroyos del centro de México: Bases para su conocimiento y conservación. Facultad de Ciencias Naturales, Universidad Autónoma de Querétaro.

[18] SOAAN, (2013). Red de Acción de Agricultura Sostenible. Guía de Mejores Prácticas para la Agricultura y Cadenas de Valor, Versión Pública 1.0. Capitulo II B $10-24$.

[19] Altieri, M. Á. \& Nicholls, C. I. (2007). Conversión agroecológica de sistemas convencionales de producción: teoría, estrategias y evaluación. Revista Ecosistemas, 16(1) 